\title{
Drug resistance genes: $p v c r t-o$ and pvmdr-1 polymorphism in patients from malaria endemic South Western Coastal Region of India
}

Shiny Joy ${ }^{1}$, Benudhar Mukhi², Susanta K. Ghosh², Rajeshwara N. Achur ${ }^{3}$, D. Channe Gowda ${ }^{4}$ and Namita Surolia ${ }^{1 *}$

\begin{abstract}
Background: Malaria is highly prevalent in many parts of India and is mostly caused by the parasite species Plasmodium vivax followed by Plasmodium falciparum. Chloroquine (CQ) is the first-line treatment for blood stage P. vivax parasites, but cases of drug resistance to CQ have been reported from India. One of the surveillance strategies which is used to monitor CQ drug resistance, is the analysis of single nucleotide polymorphisms (SNPs) of the associated gene markers. Susceptibility to CQ can also be determined by copy number assessment of multidrug resistant gene ( $m d r-1)$. The current study has examined the prevalence of SNPs in $P$. vivax orthologs of $P$. falciparum chloroquine resistant and multi-drug resistant genes ( $p v c r t-o$ and pvmdr-1, respectively) and pvmdr-1 copy number variations in isolates from the highly endemic Mangaluru city near the South Western Coastal region of India.

Methods: A total of 140 blood samples were collected from P. vivax infected patients attending Wenlock Hospital Mangaluru during July 2014 to January 2016. Out of these 140 samples, sequencing was carried out for 54 (38.5\%) and 85 (60.7\%) isolates for pvcrt-o and pvmdr-1, respectively. Single nucleotide polymorphisms (SNPs) in the pvcrt-o and pvmdr-1 genes were analysed by direct sequencing method, while copy number variations of 60 isolates (42. 8\%) were determined by real time PCR.

Results: Out of 54 clinical isolates analysed for pvcrt-o, three (5.6\%) showed K10 insertion and the rest had wild type sequence. This is the first report to show K10 insertion in P. vivax isolates from India. Further, out of 85 clinical isolates of $P$. vivax analysed for mutations in pvmdr-1 gene, only one isolate had wild type sequence $(\sim 1 \%)$ while the remaining (99\%) carried mutant alleles. Seven non-synonymous mutations with two novel mutations (I946V and Y1028C) were observed. Of all the observed mutations in pvmdr-1 gene, T958M was most highly prevalent (present in 90\% of samples) followed by F1076L (76\%), and Y976F (7\%). Amplification of pvmdr-1 gene was observed in 31.6\% of the isolates, out of 60 amplified.
\end{abstract}

Conclusion: The observed variations both in pvmdr-1 and pvcrt-o genes indicate a trend towards parasite acquiring CQ resistance in this endemic area.

Keywords: Plasmodium vivax, Chloroquine resistance markers, Copy number variation, Mangaluru city area, India

\footnotetext{
*Correspondence: surolia@jncasr.ac.in

${ }^{1}$ Molecular Biology and Genetics Unit, Jawaharlal Nehru Centre

For Advanced Scientific Research, Jakkur, Bangalore, India

Full list of author information is available at the end of the article
} 


\section{Background}

Malaria caused by Plasmodium vivax is a significant public health issue and is more prevalent than Plasmodium falciparum outside Africa, where $P$. falciparum is the predominant species [1]. Chloroquine and primaquine remains the first-line treatment for vivax malaria. Resistance to anti-malarial drugs is a major hurdle for malaria control strategies. In P. falciparum, decreased susceptibility to all the currently used anti-malarial drugs (amodiaquine, chloroquine, mefloquine, quinine, sulfadoxine-pyrimethamine) and more recently, resistance to artemisinin derivatives [2] has been observed and is a major concern. Although P. falciparum resistance to chloroquine (CQ) was reported in the 1950s, the first case of $P$. vivax resistance to CQ was reported only in 1989 from Papua New Guinea [3]. The mechanisms of $P$. vivax resistance to anti-malarials, have not been extensively studied due to the non-availability of continuous in vitro culture system. A majority of the reported studies have focused on analysing SNPs in resistant gene markers [4].

The P. falciparum orthologs for CQ-resistant genes, pvcrt-o and pvmdr-1, of $P$. vivax have been the main focus in studying the CQ resistance [5, 6]. A number of mutations in both genes have been reported. Among these, K10 insertion in pvcrt-o and several specific SNPs in $p v m d r-1$ have been identified as possible molecular markers of CQ resistance in P. vivax [6, 7]. The Y976F and F1076L, which are non-synonymous amino acid mutations of the Pvmdr-1, have been reported to correlate with CQ resistance [8-10]. However, in some studies, no significant associations have been found between these mutations and clinical response of vivax malaria to chloroquine $[5,11,12]$. Further, as in P. falciparum, copy number variations in $p v m d r 1$ has been suggested to be associated with anti-malarial resistance $[13,14]$. The Pvmdr-1 gene amplification has been shown to correlate with susceptibility of $P$. vivax to various anti-malarial drugs [10]. This amplification leads to decreased susceptibility to mefloquine and increased susceptibility to CQ [15].

India is one of the countries where $80 \%$ of the total malaria cases occur worldwide due to $P$. vivax [1]. There have been several studies reporting CQ resistance in $P$. vivax resulting in fatal malaria in India [16-19]. Mangaluru is a coastal city in Southern Karnataka state of India that has malarial resurgence since 1990. Mangaluru city and its surrounding region are highly malaria endemic. Despite high endemicity and huge health burden, no systematic epidemiological studies with respect to disease severity, clinical manifestations and drug resistance has been conducted in this region. The major malaria parasite in this region is $P$. vivax $(\sim 80 \%)$. This study is the first attempt to analyse vivax gene markers implicated in isolates obtained from this region.

\section{Methods \\ Sample collection and ethics}

The study was conducted at Wenlock District Hospital, Mangaluru. Written consent from participants were taken and blood samples were collected during the period June 2014 to December 2015. Thick and thin smears obtained by finger prick were prepared on glass slides, stained with Giemsa, and examined under light microscopy. Blood samples were collected on Whatman No. 3MM filter paper, allowed to air-dry, placed individually in plastic bags and stored at $-80^{\circ} \mathrm{C}$ until processed. A total of $140 P$. vivax positive patients (as confirmed by microscopy, RDT and 18srRNA amplification by PCR) were included in this study. The study design was in accordance with the ethical guidelines of Indian Council of Medical Research (ICMR) and the National Institutes of Health, USA. The study protocols were approved by the Institutional review board of Kuvempu University, Shivamogga, Karnataka, India, and Pennsylvania State University College of Medicine, Hershey, PA, USA.

\section{DNA extraction and species confirmation}

Genomic DNA was extracted from filter paper spots using Chelex-100 reagents (Chelex ${ }^{\circledR}-100$, Himedia, USA) as described [20]. Briefly, each filter paper punch was incubated with $0.5 \%$ saponin in phosphate buffered saline at $4{ }^{\circ} \mathrm{C}$ overnight. The punches were washed with $1 \times$ PBS for 30 min, transferred to new tubes containing 5\% Chelex-100 and vortexed for $30 \mathrm{~s}$; followed by heating at $99^{\circ} \mathrm{C}$ for $15 \mathrm{~min}$ and centrifuged at $14 \mathrm{~K}$ for $2 \mathrm{~min}$. Supernatant was collected and stored at $-20^{\circ} \mathrm{C}$ until used.

Plasmodium vivax infection identified by microscopy was confirmed by PCR analysis of $18 \mathrm{~s}$ ribosomal RNA of parasites in all samples. One genus-specific (Plasmodium) and two species-specific (falciparum and vivax) sets of primers were used for PCR analysis, as described previously [21].

\section{Amplification of chloroquine resistance associated genes}

The $p v c r t-o$ and $p v m d r-1$ genes were amplified using primers and reaction conditions as described [22, 23]. Amplification of target gene fragments were performed by PCR using $30 \mathrm{ng}$ template DNA and Phusion ${ }^{\circledR}$ High-Fidelity DNA Polymerase. The PCR cycle conditions were as follows: initial denaturation at $98{ }^{\circ} \mathrm{C}$ for $30 \mathrm{~s}, 30$ cycles of denaturation at $98{ }^{\circ} \mathrm{C}$ each for $10 \mathrm{~s}$, annealing at primerdependent temperature for $30 \mathrm{~s}$, and extension at $72{ }^{\circ} \mathrm{C}$ for $1.15 \mathrm{~min}$ followed by final extension of $72{ }^{\circ} \mathrm{C}$ for $5 \mathrm{~min}$. Optimal annealing temperature was $61{ }^{\circ} \mathrm{C}$ for both the genes. 


\section{Sequence analysis}

The PCR amplified gene products were extracted from gels using Gel Extraction kit (Sigma-Aldrich, St Louis, MO, USA) and the extracted DNA was quantified by nanodrop. Sequencing of genes from each isolate was performed on an ABI Prism 377 DNA Sequencer equipped with semi adaptive version 3.0. Nucleotide sequences were analysed using blast and Bio Edit Sequence Alignment Editor and compared with reference sequences of Gen-Bank accession numbers, AF314649 and AY571984 for $p v c r t-o$ and $p v m d r-1$, respectively. Amplification and sequencing were repeated to confirm that the observed SNP variants were not due to PCR or sequencing errors.

\section{Determination of pvmdr-1 gene copy numbers}

$P v m d r-1$ copy number was determined by SYBR green based quantitative PCR using the primers as described [15]. Amplified products of pvmdr-1 and pvaldolase (as internal control) were cloned (InsTAclone PCR Cloning Kit (Thermo Scientific Company, USA) into the vector pTZ57R/T and used as calibrators for the assay. For both the genes, $20 \mu \mathrm{L}$ reaction contained of $10 \mu \mathrm{L}$ of SYBR green mix (Bio-Rad Laboratories, USA), $0.125 \mu \mathrm{M}$ of each primer and 1-10 ng genomic DNA. Amplification included a template denaturation step for $4 \mathrm{~min}$ at $95^{\circ} \mathrm{C}$, followed by 38 cycles of $95{ }^{\circ} \mathrm{C}$ for $30 \mathrm{~s}$ and $60{ }^{\circ} \mathrm{C}$ for $30 \mathrm{~s}$ and $72{ }^{\circ} \mathrm{C}$ for $30 \mathrm{~s}$ with fluorescence acquisition at the end of each extension step. Amplification was immediately followed by melting at $65-95{ }^{\circ} \mathrm{C}$ with stepwise temperature increase of $0.5{ }^{\circ} \mathrm{C}$ with fluorescence acquisition at each temperature transition. The assays were repeated. A copy number of $<1.6$ was considered a single copy, and a copy number of $\geq 1.6$ was considered multiple copies.

\section{Results}

\section{Analysis of pvcrt-o gene polymorphisms}

The pvcrt-o gene from 54 isolates of $P$. vivax from Mangaluru were sequenced. Of the 54 isolates analysed, wild type sequence was observed in 51 isolates (94\%) and 3 isolates (5.5\%) showed insertion of three bases, AAG, leading to $\mathrm{K} 10$ insertion in the first exon when compared with reference $p v c r t$-o sequence.

\section{Analysis of pvmdr - 1 gene polymorphisms and copy number assessment}

The $p v m d r-1$ gene amplified from 85 isolates was sequenced. Seven non-synonymous mutations (I946V, T958M, Y976F, F979S, M980V, Y1028C and F1076L) were observed. Among these, I946V and Y1028C mutations were observed for the first time from this region. Prevalence of the Y976F mutation was found to be $7.1 \%$ while F1076L mutation was 54.5\%. The most prevalent and dominant $(90.6 \%, \mathrm{n}=77$ ) mutation was T958M (Table 1 ).
Table 1 Non synonymous mutations observed among isolates

\begin{tabular}{llc}
\hline No & Non synonymous mutations & Isolates $\mathbf{N}(\%)$ \\
\hline 1 & T958M & $77(90.6)$ \\
2 & F979S & $1(1.2)$ \\
3 & M980V & $1(1.2)$ \\
4 & F1076L & $65(76.5)$ \\
5 & I946V & $1(1.2)$ \\
6 & Y976F & $6(7.1)$ \\
7 & Y1028C & $1(1.2)$ \\
\hline
\end{tabular}

The F979S and M980V mutations were observed in one sample (1.2\% prevalence) alone. $P v m d r-1$ from one isolate had $100 \%$ homology with wild type gene sequence.

Ten different haplotypes of $p v m d r-1$ were observed including one wild type. Single mutants either $958_{M}$ or $1076_{\mathrm{L}}$, double mutants $958_{\mathrm{M}} 976_{\mathrm{F}}, 958_{\mathrm{M}} 1076_{\mathrm{L}}$ and $976_{\mathrm{F}}$ $1076_{\mathrm{L}}$; triple mutants $958_{\mathrm{M}} 976_{\mathrm{F}} 1076_{\mathrm{L}}, 958_{\mathrm{M}} 1028_{\mathrm{C}} 1076_{\mathrm{L}}$ and $946_{\mathrm{V}} 958_{\mathrm{M}} 1076_{\mathrm{L}}$; and quadruple mutants $958_{\mathrm{M}} 979_{\mathrm{S}}$ $980_{\mathrm{V}} 1076_{\mathrm{L}}$ in different frequencies (Table 2).

\section{Pvmdr-1 copy number assessment}

The pvmdr-1 copy number was analysed for 60 isolates. Of these, a majority of isolates $(68.3 \%, \mathrm{n}=41)$ had single gene copy while the remaining $(31.6 \%, \mathrm{n}=19)$ had more than one, i.e.; two, three or four copies.

\section{Discussion}

This study has identified CQ resistance-associated genotypes of $P$. vivax in the highly malaria endemic area of Mangaluru city and its surrounding regions. Importantly, this is the single study so far to analyse the drug resistance associated SNPs from this region. The identified genotypes include those having SNPs in pvcrt-o and pvmdr-1, and also those with copy number variations in $p v m d r-1$ gene. In case of pvcrt-o,

Table 2 Different haplotypes having mutations in Pvmdr-1 gene

\begin{tabular}{lc}
\hline Haplotype & Isolates number (\%) \\
\hline $958_{M}$ & $16(18.8)$ \\
$1076_{L}$ & $6(7)$ \\
$958_{M} 976_{F}$ & $3(3.5)$ \\
$958_{M} 107 \sigma_{L}$ & $53(62.4)$ \\
$976_{F} 107 \sigma_{L}$ & $1(1.2)$ \\
$958_{M} 976_{F} 1076_{L}$ & $2(2.4)$ \\
$958_{M} 1028_{C} 107 \sigma_{L}$ & $1(1.2)$ \\
$946_{V} 958_{M} 1076_{L}$ & $1(1.2)$ \\
$958_{M} 979_{S} 980_{V} 1076_{L}$ & $1(1.2)$ \\
\hline
\end{tabular}


$5.6 \%$ of isolates carried an insertion of three bases, namely AAG, in the first exon. This is the first study from India reporting K10 insertion in pvcrt-o. Earlier studies from Indonesia and Thailand reported a significant increase in $\mathrm{CQ} \mathrm{IC}_{50}$ that correlated with $\mathrm{K} 10$ insertion and Y976F mutation in pvcrt-o and pvmdr-1 respectively [24]. In our study, Y976F mutant was also observed among the isolates analysed with the prevalence rate of $7.1 \%$. The previous clinical studies from India $[8,25]$ reported susceptibility towards CQ and the mutant Y976F was not observed in these two studies. The major haplotype in our study was found to be $958_{\mathrm{M}} 1076_{\mathrm{L}}$ similar to the studies reported earlier [25, 26]. This suggest that $P$. vivax isolates from Mangaluru are susceptible to $C Q$, but the occurrence of both Y976F mutants and K10 insertion though at a low rate may be an indication that chloroquine resistance in this geographical area will surface in near future.

Two novel mutations, I946V and Y1028C are observed in $p v m d r-1$ at the rate of $1.2 \%(\mathrm{n}=1)$. While $\mathrm{Y} 1028 \mathrm{C}$ is present in the extracellular loop and the other mutation, I946V is on the transmembrane domain of the pvmdr-1 gene where the other reported T958M mutation is present. T958M mutation is observed in majority of the samples (90.6\%) analysed in this study. Since T958M mutation is present in isolates from countries having low to high levels of CQ resistance, T958M appears to be an allelic variant of the wild type and is most likely not associated with CQ resistance $[9,12,27]$. The other two rare mutations, F979S, M980V, observed in this study were also found in isolates from Nepal [28]. This similarity in parasite population is may be due to the geographical similarity between India and Nepal. Overall the role of these mutations cannot be determined until they correlate with clinical studies.

Among 60 isolates for which copy number of $p v m d r-$ 1 gene was analysed, more than half $(68.3 \%)$ of the isolates have single copy gene and the remaining $31.6 \%$ carried multiple copies. Studies have reported that multiple copies inversely correlate with CQ resistance. So, increased percentage of isolates having single copy suggest decreased susceptibility to CQ. However, in vitro together with clinical phenotypic studies are required to confirm the drug susceptibility in this region. Further, since phenotypic studies have not been well established for $P$. vivax, results presented here on pvcrt-o and pvmdr-1 markers should serve as the base for future studies, monitoring drug resistance in this region. Also, though K-10 insertion is found less frequent, this calls for attention to conduct regular monitoring for the drug resistance in this region for decisions on drug policy.

\section{Conclusion}

Results of the current study show that, the pvcrt-o and pvmdr-1 gene variants implicated in $P$. vivax CQ resistance are less frequent in Mangaluru. This frequency is an indicator of low $P$. vivax drug resistance, though reflecting a beginning of the trend. Hence, continuous monitoring of drug resistant markers and therapeutic efficacy studies would be desirable for proper management and administration of anti-malarial drugs.

\section{Abbreviations \\ API: annual parasite index; CQR: chloroquine resistance; Pvmdr-1: Plasmodium vivax multidrug resistant 1 gene; Pvcrt-o: Plasmodium vivax chloroquine resist- ance transporter; WHO: World Health Organization; SNP: single nucleotide polymorphisms; PBS: phosphate buffered saline.}

\section{Authors' contributions}

NS conceptualized and designed the study; SJ performed the study; BM conducted the data acquisition and analysis. NS analysed and interpreted the data; SJ wrote the manuscript; NS and DCG edited the manuscript; NS and DCG provided study resources. All authors read and approved the final manuscript.

\section{Author details \\ ${ }^{1}$ Molecular Biology and Genetics Unit, Jawaharlal Nehru Centre For Advanced Scientific Research, Jakkur, Bangalore, India. ${ }^{2}$ Department of Biological Control, National Institute of Malaria Research, Poojanahalli, Bangalore, India. ${ }^{3}$ Department of Biochemistry, Kuvempu University, Shivamogga District, Shankaraghatta, Karnataka, India. ${ }^{4}$ Department of Biochemistry and Molecular Biology, The Pennsylvania State University College of Medicine, 500 University Drive, Hershey, PA 17033, USA.}

\section{Acknowledgements}

We would like to thank Mr. A. Bapaiaha for helping me with sample collection. We also thank Mrs. Anitha C. A., Corefacility, JNCASR, for gene sequencing.

\section{Competing interests}

The authors declare that they have no competing interests.

\section{Availability of data and materials}

The data used in this study is archived in corresponding authors university and available from the corresponding author upon reasonable request.

\section{Consent for publication}

Not applicable.

\section{Ethics approval and consent to participate}

The ethics Committee of Kuvempu University, Shivamogga, Karnataka, India, and the Institutional Review Board of the Penn State University College of Medicine, USA, have approved this study. Informed written consent was obtained from all the study participants.

\section{Funding}

This work was supported by the Grant D43 TW008268 from the Fogarty International Center of the National Institutes of Health, USA, under the Global Infectious Diseases Program. The funders had no role in study design, data collection, and analysis, decision to publish, or preparation of the manuscript.

\section{Publisher's Note}

Springer Nature remains neutral with regard to jurisdictional claims in published maps and institutional affiliations.

Received: 20 August 2017 Accepted: 15 January 2018

Published online: 19 January 2018 


\section{References}

1. WHO. World malaria report 2015. Geneva: World Health Organization; 2015. p. 243.

2. WHO. Guidelines for the treatment of malaria. 2nd ed. Geneva: World Health Organization; 2010. p. 210.

3. Rieckmann $\mathrm{KH}$, Davis DR, Hutton DC. Plasmodium vivax resistance to chloroquine? Lancet. 1989:334:1183-4.

4. Plowe CV. Monitoring antimalarial drug resistance: making the most of the tools at hand. J Exp Biol. 2003;206:3745-52.

5. Nomura T, Carlton JM, Baird JK, del Portillo HA, Fryauff DJ, Rathore D, et al. Evidence for different mechanisms of chloroquine resistance in 2 Plasmodium species that cause human malaria. J Infect Dis. 2001;183:1653-61.

6. Brega S, Meslin B, de Monbrison F, Severini C, Gradoni L, Udomsangpetch $R$, et al. Identification of the Plasmodium vivax mdr-like gene ( $p v m d r 1$ ) and analysis of single-nucleotide polymorphisms among isolates from different areas of endemicity. J Infect Dis. 2005;191:272-7.

7. Sá JM, Yamamoto MM, Fernandez-Becerra C, de Azevedo MF, Papakrivos $J$, Naudé B, et al. Expression and function of pvcrt-o, a Plasmodium vivax ortholog of pfcrt, in Plasmodium falciparum and Dictyostelium discoideum. Mol Biochem Parasitol. 2006:150:219-28.

8. Ganguly S, Saha P, Guha SK, Das S, Bera DK, Biswas A, et al. In vivo therapeutic efficacy of chloroquine alone or in combination with primaquine against vivax malaria in Kolkata, West Bengal, India, and polymorphism in pvmdr1 and pvcrt-o genes. Antimicrob Agents Chemother. 2013:57:1246-51.

9. Barnadas C, Ratsimbasoa A, Tichit M, Bouchier C, Jahevitra M, Picot S, et al. Plasmodium vivax resistance to chloroquine in Madagascar: clinical efficacy and polymorphisms in pvmdr1 and pvcrt-o genes. Antimicrob Agents Chemother. 2008;52:4233-40.

10. Suwanarusk R, Chavchich M, Russell B, Jaidee A, Chalfein F, Barends M, et al. Amplification of pvmdr1 associated with multidrugresistant Plasmodium vivax. J Infect Dis. 2008;198:1558-64.

11. Orjuela-Sánchez P, Filho FSDS, Machado-Lima A, Chehuan YF, Costa MRF, Alecrim MDGC, et al. Analysis of single-nucleotide polymorphisms in the crt-o and mdr1 genes of Plasmodium vivax among chloroquine-resistant isolates from the Brazilian Amazon region. Antimicrob Agents Chemother. 2009:53:3561-4

12. Sa JM, Nomura T, Neves J, Baird JK, Wellems TE, del Portillo HA. Plasmodium vivax: allele variants of the mdr1 gene do not associate with chloroquine resistance among isolates from Brazil, Papua, and monkey-adapted strains. Exp Parasitol. 2005;109:256-9.

13. Costa GL, Amaral LC, Fontes CJ, Carvalho LH. Assessment of copy number variation in genes related to drug resistance in Plasmodium vivax and Plasmodium falciparum isolates from the Brazilian Amazon and a systematic review of the literature. Malar J. 2017;16(1):1-11.

14. Imwong M, Pukrittayakamee S, Pongtavornpinyo W, Nakeesathit S, Nair S, Newton $\mathrm{P}$, et al. Gene amplification of the multidrug resistance 1 gene of Plasmodium vivax isolates from Thailand, Laos, and Myanmar. Antimicrob Agents Chemother. 2008;52:2657-9.
15. Vargas-Rodríguez RDCM, Bastos MDS, Menezes MJ, Orjuela-Sánchez P, Ferreira MU. Single-nucleotide polymorphism and copy number variation of the multidrug resistance-1 locus of Plasmodium vivax: local and global patterns. Am J Trop Med Hyg. 2012;87:813-21.

16. Dua VK, Kar PK, Sharma VP. Chloroquine resistant Plasmodium vivax malaria in India. Trop Med Int Health. 1996;1:816-9.

17. Garg M, Gopinathan N, Bodhe PKN. Vivax malaria resistant to chloroquine: case reports from Bombay. Trans R Soc Trop Med Hyg. 1995;89:656-7.

18. Kshirsagar NA, Gogtay NJ, Rajgor D, Dalvi SS, Wakde M, Gogtay NJ, et al. An unusual case of multidrug-resistant Plasmodium vivax malaria in Mumbai (Bombay), India. Ann Trop Med Parasitol. 2000;94:189-90.

19. Nandy A, Addy M, Maji AK, Bandyopdhyay A. Monitoring the chloroquine sensitivity of Plasmodium vivax from Calcutta and Orissa, India. Ann Trop Med Parasitol. 2003:97:215-20.

20. Plowe CV, Djimdé A, Bouare M, Doumbo O, Wellems TE. Pyrimethamine and proguanil resistance conferring mutations in Plasmodium falciparum dihydrofolate reductase: polymerase chain reaction methods for surveillance in Africa. Am J Trop Med Hyg. 1995:52:565-8.

21. Kochar DK, Das A, Kochar SK, Saxena V, Sirohi P, Garg S, et al. Severe Plasmodium vivax malaria: a report on serial cases from Bikaner in northwestern India. Am J Trop Med Hyg. 2009;80:194-8.

22. Lu F, Wang B, Cao J, Sattabongkot J, Zhou H, Zhu G, et al. Prevalence of drug resistance-associated gene mutations in Plasmodium vivax in central china. Korean J Parasitol. 2012;50:379-84.

23. Golassa L, Erko B, Baliraine FN, Aseffa A, Swedberg G. Polymorphisms in chloroquine resistance-associated genes in Plasmodium vivax in Ethiopia. Malar J. 2015:14:164.

24. Suwanarusk R, Russell B, Chavchich M, Chalfein F, Kenangalem E, Kosaisavee $\mathrm{V}$, et al. Chloroquine resistant Plasmodium vivax: in vitro characterisation and association with molecular polymorphisms. PLOS ONE. 2007;2:e1089.

25. Shalini S, Chaudhuri S, Sutton PL, Mishra N, Srivastava N, David JK, et al. Chloroquine efficacy studies confirm drug susceptibility of Plasmodium vivax in Chennai, India. Malar J. 2014;13:129.

26. Cerón LG, Montoya A, Gómez JCC, Cerritos R, Santillán F, Sandoval MA Genetic diversity and natural selection of Plasmodium vivax multi-drug resistant gene (pvmdr1) in Mesoamerica. Malar J. 2017;16:261.

27. Schousboe ML, Ranjitkar S, Rajakaruna RS, Amerasinghe PH, Morales $F$, Pearce $R$, et al. Multiple origins of mutations in the mdr1 gene. A putative marker of chloroquine resistance in P. vivax. PLoS Negl Trop Dis. 2015;9:e0004196

28. Ranjitkar S, Schousboe ML, Thomsen TT, Adhikari M, Kapel CM, Bygbjerg IC, et al. Prevalence of molecular markers of anti-malarial drug resistance in Plasmodium vivax and Plasmodium falciparum in two districts of Nepal. Malar J. 2011;10:75

\section{Submit your next manuscript to BioMed Central and we will help you at every step:}

- We accept pre-submission inquiries

- Our selector tool helps you to find the most relevant journal

- We provide round the clock customer support

- Convenient online submission

- Thorough peer review

- Inclusion in PubMed and all major indexing services

- Maximum visibility for your research

Submit your manuscript at www.biomedcentral.com/submit
BioMed Central 